\title{
Emerging oral immunomodulating agents - focus on teriflunomide for the treatment of multiple sclerosis
}

This article was published in the following Dove Press journal:

Degenerative Neurological and Neuromuscular Disease

10 March 2012

Number of times this article has been viewed

\section{Enyioma Nwankwo \\ Douglas R Allington \\ Michael P Rivey}

Pharmacy Practice Department, University of Montana, Missoula, MT, USA
Correspondence: Douglas Allington Pharmacy Practice Department, University of Montana, 32 Campus Drive, Missoula, MT 59812, USA

Tel +l 4062432498

Fax +l 4062434353

Email douglas.allington@umontana.edu

\begin{abstract}
Treatment for multiple sclerosis (MS), a chronic disease of the central nervous system, has historically relied exclusively on the use of injectable therapies. As the disease requires lifelong therapy, the development of oral therapies that are safe and effective would provide a more convenient dosage form that may improve patient compliance. One oral medication (fingolimod) was recently approved for treatment of MS. Teriflunomide, an immunomodulator, is one of four oral therapies currently undergoing Phase III trials. Teriflunomide exerts its clinical effects via selective inhibition of de novo pyrimidine synthesis, primarily targeting proliferating $\mathrm{T}$ and $\mathrm{B}$ lymphocytes in the periphery. Teriflunomide was effective as monotherapy in reducing magnetic resonance imaging lesions and annual relapse rates in Phase II and Phase III trials. When teriflunomide was added to interferon or glatiramer acetate therapy in Phase II trials, teriflunomide reduced magnetic resonance imaging lesions significantly more than either interferon or glatiramer acetate alone. Treatment-emergent adverse events occurred at similar rates among all groups in teriflunomide studies, with a trend towards a higher treatment emergent adverse events rate in the higher dosage group of teriflunomide (14 mg daily). Treatment discontinuations in teriflunomide trials were relatively low, suggesting that teriflunomide monotherapy is well tolerated. This article reviews the mode of action of teriflunomide, its pharmacokinetic, clinical efficacy, and safety profiles.
\end{abstract}

Keywords: clinical trials, oral drugs, pharmacokinetics, pharmacology

\section{Introduction}

Multiple sclerosis (MS) is a chronic inflammatory disease involving the central nervous system (CNS). Typical pathology findings of MS include axonal injury, loss of neurons and supporting structures, impaired remyelination, and chronic plaques. These cellular and tissue changes commonly produce significant limitations of function and considerable infirmity in patients. MS affects an estimated 2.5 million adults worldwide and is the leading cause of nontraumatic neurological disability in this age group. ${ }^{1}$ Several new oral medications have either recently been approved for use in MS or are currently undergoing clinical Phase II or III testing. The purpose of this article is to review the pharmacology, mode of action, pharmacokinetics, and clinical trial results of teriflunomide.

\section{Epidemiology}

MS is known to occur in genetically predisposed individuals who have been exposed to an unknown environmental trigger. Results of elegant epidemiological and complex genetic mapping studies have identified particular populations at risk. 
Individuals living above or below the 37 th latitude demonstrate a different risk of acquiring MS. In the United States, MS occurs in 50-100 per 100,000 individuals living in regions of the country above the 37 th parallel whereas rates of 20-30 per 100,000 are typical for populations below this parallel. A similar difference in the reported prevalence rates of MS also occurs on a worldwide scale in populations living above or below the 37 th parallel in Europe, countries of the Mediterranean, Australia, and New Zealand. However, outliers or clusters of MS populations not "fitting" this basic geographic pattern are found in each region. MS prevalence rates throughout Asia, Africa, and Latin America are comparatively low. ${ }^{2}$ Data sources for reported MS estimates are generated from population surveys, hospital records and national health registries. It should be noted that variability in the reported rates of MS are likely influenced by use of different MS diagnostic criteria, patient access to physicians, and the availability of specialized diagnostic equipment. ${ }^{3}$

Epidemiological data provide clues suggesting genetic and racial markers associated with acquiring MS as well as potential environmental triggers. MS is much more likely to occur in Caucasians versus indigenous peoples of Hawaii, New Zealand, and Canada despite sharing geographically similar population distribution. MS prevalence disparities also exist among Russians of European versus Asian descent. ${ }^{3}$ On average, MS has a typical onset of disease in young adults at 30 years of age and occurs more frequently in women than men. ${ }^{4}$

Like many diseases, MS can present with variable clinical severity. Clinically isolated syndrome (CIS) causes neurological symptoms produced by a single CNS demyelinating lesion. Patients with optic neuritis or other signs and symptoms produced by lesions in the brainstem, spinal cord, or cerebral hemispheres are typical initial presentations associated with CIS. ${ }^{5}$ Many patients with CIS, thirty to seventy percent, progress to clinically definite multiple sclerosis (CDMS) within 2-10 years of initial clinical symptoms. ${ }^{6,7}$ Another subset of patients with so-called "silent lesions" are classified as having radiologically isolated syndrome (RIS). RIS is characterized by CNS lesions found by magnetic resonance imaging (MRI) in a patient who demonstrates no clinical signs or symptoms; approximately $30 \%$ of individuals with RIS progress to CDMS. ${ }^{8}$ Ongoing research efforts are being directed at identifying risk characteristics that are predictive of progression to CDMS in patients with CIS or RIS, as well as potential therapies that would prevent or delay progression to CDMS.
Diagnostic criteria for MS have evolved over time due to advances in neuroimaging techniques. The MacDonald criteria that was last revised in 2010 utilizes the presence and timing of characteristic neurologic signs or symptoms, and data from MRI images or abnormal visual evoked potential results. Essential aspects for the diagnosis of MS include evidence of CNS lesions by MRI that produce symptoms disseminated in space and time. CDMS can be confirmed at initial presentation of symptoms if the symptoms are characteristic of a demyelinating event in the CNS, in the absence of fever or infection, but must also include additional objective imaging data such as the presence of T2 and/or gadoliniumenhancing CNS lesions. ${ }^{9}$

Approximately $85 \%$ of MS patients who progress to CDMS will clinically express a relapsing-remitting (RRMS) pattern of disease activity. RRMS is characterized by periods of neurological deterioration called attacks, exacerbations, or relapses which last from 1 day to several weeks. In RRMS, relapses are followed by periods of improved or normal CNS function (remittance). Seventy percent of patients with RRMS eventually exhibit a secondary progressive pattern, SPMS. ${ }^{10}$ In SPMS, relapses are not followed by periods of full neurological recovery and deficits accumulate as the MS progresses. ${ }^{11}$ The accumulated deficits must persist for 6 or more months to meet the criteria for SPMS. ${ }^{12}$

The remaining estimated $15 \%$ of CDMS patients experience a primary progressive clinical course. Central to the diagnosis of primary progressive MS is a 12-month period of disease progression and the presence of at least two of three supporting criteria including (a) evidence of dissemination in space by the presence of one or more T2 lesions in an area of the brain commonly affected in MS, (b) evidence of dissemination in space by two or more T2 lesions in the spinal cord, and (c) elevated oligoclonal bands and/or an elevated immunoglobulin $\mathrm{G}$ index found within cerebrospinal fluid. ${ }^{9}$

Exposure to an environmental trigger or toxin in a predisposed individual is believed to cause the initial sequence of events that lead to MS. ${ }^{13}$ Initial CNS inflammation precipitates further dysregulated innate and adaptive immune responses leading to demyelinated axons. ${ }^{14}$ Repair of the damaged neurons is abnormal and dysfunctional. ${ }^{15}$ Elegant theories have been advanced to link MS clinical disease expressions, including RRMS or SPMS, with the location of brain lesions, total lesion burden, ${ }^{16,17}$ or with specific histological expressions within CNS lesions. ${ }^{18,19}$ Over time, focal demyelinated CNS lesions turn into chronic plaques with histological evidence of persistent axonal injury, 
impaired remyelination, loss of neurons, supporting glial and oligodendrite cells, and general brain atrophy. ${ }^{20-22}$

\section{Pathophysiology}

Patients with MS demonstrate abnormalities in T- and B-cell function. During the MS disease process, antigens present to naïve $\mathrm{T}$ cells promoting phenotypic expression of Th-1, Th-2, and Th-17 under the influence of specific interleukins. On activation, $\mathrm{T}$ cells travel from the periphery across the blood-brain barrier (BBB) with the aid of vascular adhesion molecules. After entering the CNS, T cells are exposed to additional antigens causing an abnormal response directed against myelin via production of cytokines, tumor necrosis factors, and interleukins with the recruitment of other inflammatory cells. ${ }^{23}$ Cellular and molecular components involved in MS immunology are summarized in Figure 1. The presence of specific oligoclonal antibodies and elevated immunoglobulin G levels in the cerebrospinal fluid has long pointed to a role of B cells in the development of MS. Only recently has the complex interaction between $\mathrm{B}$ cells and $\mathrm{T}$ cells in MS been established ${ }^{24}$ and investigations of agents' therapeutic manipulation of B-cell targets have reached human clinical trials.

The complex cascade of cellular and molecular responses in MS provides numerous potential targets for preventing acquisition, modifying the clinical course, or halting progression of MS. Research in the past decade has produced several promising agents that reduce MS relapse rates or lessen plaque burden. Proposed sites of action for several new agents are provided in Figure 2. Teriflunomide is one such agent that has been evaluated both as monotherapy and in combination with other medications for the treatment of RRMS and SPMS. Teriflunomide is the active metabolite of leflunomide, an agent widely used in the treatment of rheumatoid arthritis. The purpose of this article is to review existing data and evaluate the potential benefit of teriflunomide in the treatment of MS.

\section{Mode of action of teriflunomide Inhibition of pyrimidine synthesis}

Teriflunomide predominantly exerts antiproliferative and anti-inflammatory effects via noncompetitive, selective inhibition of the mitochondrial enzyme dihydroorotate (DHODH). ${ }^{25} \mathrm{DHODH}$ is the rate-limiting enzyme in the de novo synthesis of pyrimidines. ${ }^{26}$ Inhibition of DHODH leads to cell-cycle arrest in the G1 phase of T cells, B cells, and other rapidly dividing cell populations. ${ }^{27-29}$ Pyrimidine inhibition and the resultant suppression of the effector functions of activated lymphocytes is the primary proposed mechanism through which teriflunomide moderates the effects of an overactive immune system..$^{25,30}$ The cytotoxic effects of teriflunomide are limited to cells that require

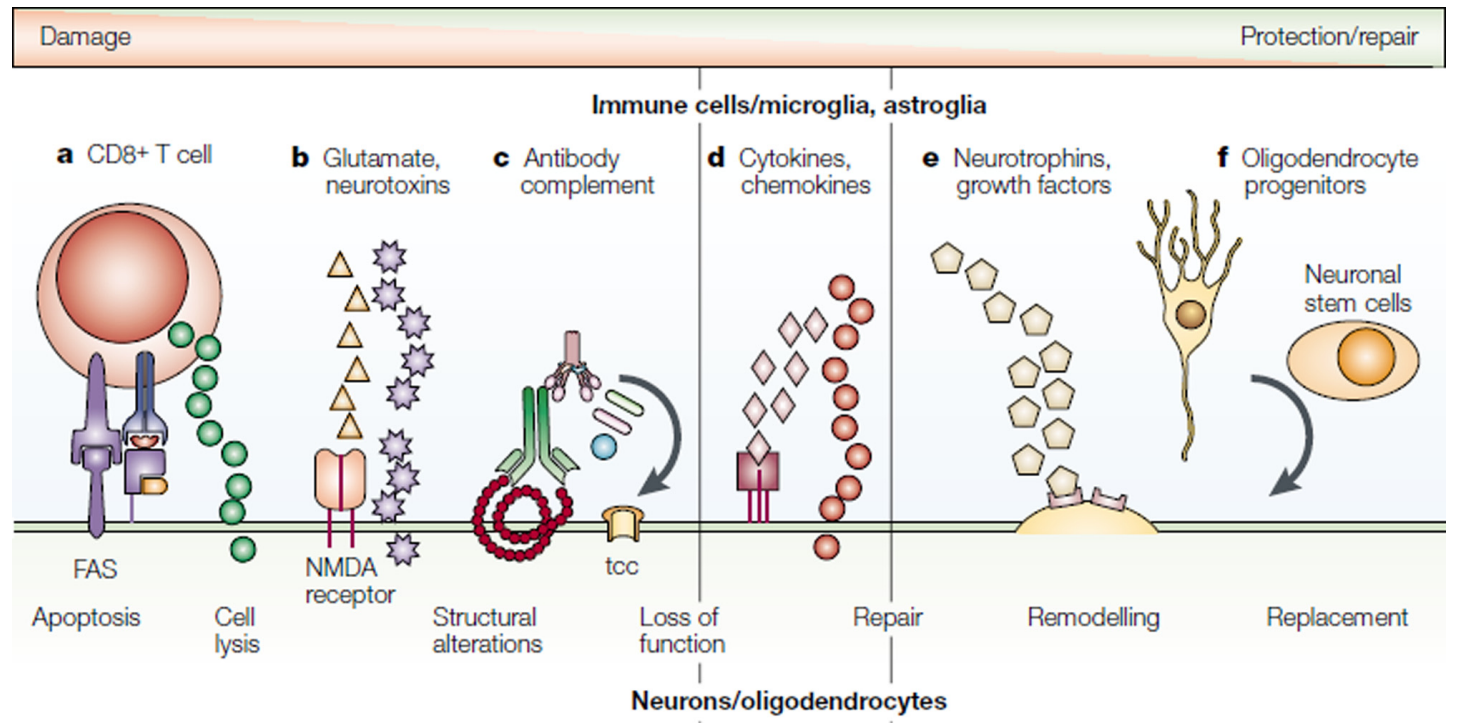

Figure I Molecular and cellular changes in multiple sclerosis. The mechanisms of direct neuronal and oligodendrocyte damage and repair are shown. They include: (A) direct antigen-specific attack of $\mathrm{CD}^{+} \mathrm{T}$ cells, with the discharge of cytotoxic granules and the ligation of the fatty acid synthase molecule; (B) release by glial cells of excitatory amino acids and neurotoxins, which bind to glutamate receptors or directly target the cells; (C) binding of a specific antibody, leading to complement activation and formation of the membrane-attacking terminal complement complex and also, possibly, promoting remyelination; (D) release of cytokines, matrix metalloproteinases, and metabolites from macrophages, microglia, $T$ cells, and astroglia that are involved in inflammation, neurodegeneration, and neuroprotection; (E) release by glial cells and CD4 $\mathrm{T}$ cells of neurotrophins, which are involved in neuroprotection and regeneration; and (F) migration of oligodendrocyte progenitor cells and neuronal stem cells to the lesion, which replace damaged oligodendrocytes and neurons.

Note: Reprinted by permission from Macmillan Publishers Ltd: Nature Reviews Neuroscience. Hemmer B, Archelos JJ, Hartung HP. New concepts in the immunopatogenesis of multiple sclerosis. Nat Rev Neurosci. 2002;3(4):29I-30I, copyright 2002.

Abbreviations: FAS, fatty acid synthase; NMDA, N-methyl-D-aspartate; tcc, terminal complement complex. 


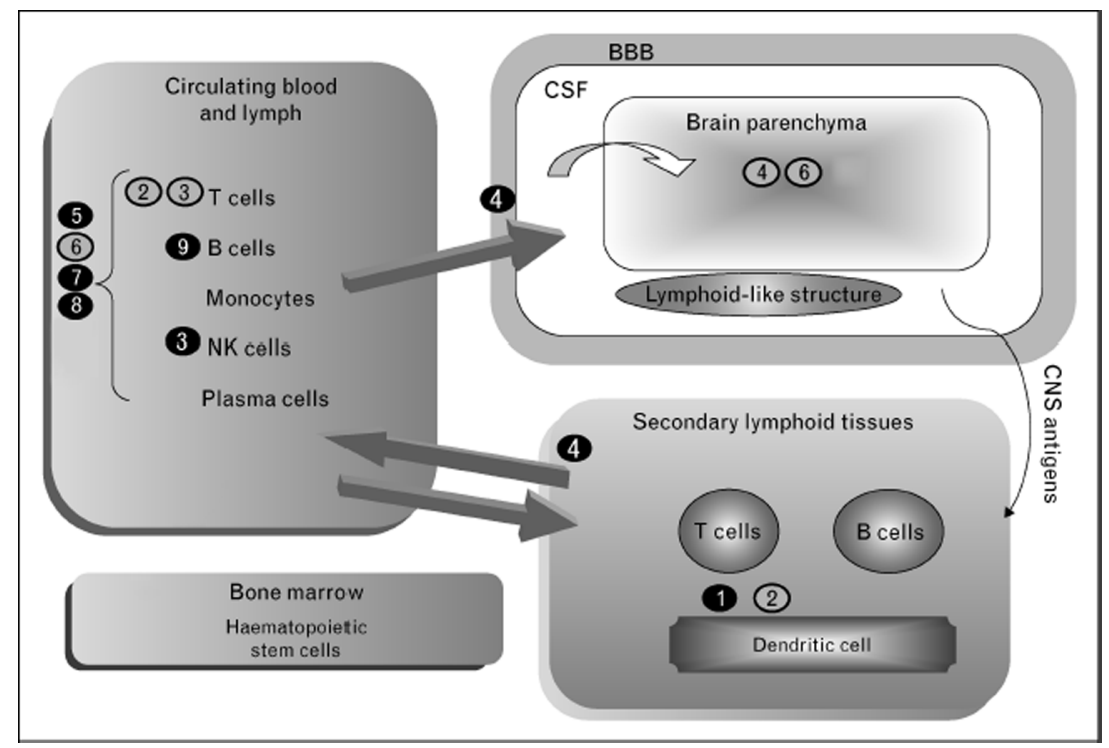

Figure 2 Multiple sclerosis immunology and proposed site of action for novel multiple sclerosis agents.

Notes: CNS antigens flow into secondary lymphoid tissues where circulating $T$ cells become activated by antigen-presenting cells carrying antigen and costimulatory molecules. Peripherally activated immune cells can access the BBB and infiltrate the CNS through steps of ahesion, chemoattraction and transmigration. Hematopoietic stem cells can replenish circulating immune cell subsets. Compartmentalized CNS processes of inflammation and degeneration may occur relatively independent of peripheral immune activation. Block arrows indicate flow of inflammatory cells. Numbered circles indicate therapies based on their main presumed sites of action. Alternative names of drugs are indicated in parenthesis. Black circles indicate strong supporting evidence, grey circles indicate weaker evidence. I, BHT-3309; 2, MBP8298 (dirucotide); 3, daclizumab; 4, FTY720 (fingolimod); 5, teriflunomide, laquinimod; 6, BG 2; 7, cladribine; 8, alemtuzumab; 9, rituximab, ocrelizumab. Reproduced by permission from Wolther Kluwer Health: Current Opinion in Neurology. Giacomini PS, Darlington PJ, Bar-Or A. Emerging multiple sclerosis disease-modifying therapies. Curr Opin Neurol. 2009;22(3):226-232, copyright 2009.

Abbreviations: BBB, blood-brain barrier; CNS, central nervous system; CSF, cerebrospinal fluid; NK, natural killer.

DHODH for pyrimidine synthesis but slower-replicating cells in the gastrointestinal tract and the hematopoietic system are spared since they rely on salvage pathways for pyrimidine synthesis that do not require induction of DHODH. ${ }^{30,31}$ The specific hematopoietic cells which rely on salvage pathways for pyrimidine synthesis are the resting lymphocytes. In contrast, blasting lymphocytes that are associated with acute inflammatory response require an eightfold expansion of their pyrimidine pools in order to exert their effects and are therefore reliant on de novo pyrimidine synthesis. ${ }^{32}$ Thus, the effects of teriflunomide are focused on blasting lymphocytes while sparing homeostatically expanding lymphocytes and resting lymphocytes as depicted in Figure 3.

DNA synthesis is dependent on pyrimidine and purine nucleotides. However, purine pools need only to expand about twofold in blasting lymphocytes (compared to the previously noted eightfold pyrimidine pool expansion), indicating that pyrimidine nucleotides are essential for DNA synthesis in this cell population. In addition, inhibition of pyrimidine synthesis blunts rather than causes an increase in purine de novo synthesis. ${ }^{30,32}$ Despite the known biochemical interaction of pyrimidine and purine nucleotides to support lymphocyte function, the clinical effects of pyrimidine inhibition by teriflunomide have not been compared to the effects of purine antagonists. It is therefore unknown whether or not teriflunomide possesses an advantage over such medications.

Other functions of pyrimidines that are inhibited by teriflunomide include membrane biosynthesis and glycosylation of lipids, proteins, and cytokines in immune cells. ${ }^{31,33,34}$ Exogenous administration of pyrimidine completely rescues the affected cells from the antiproliferative

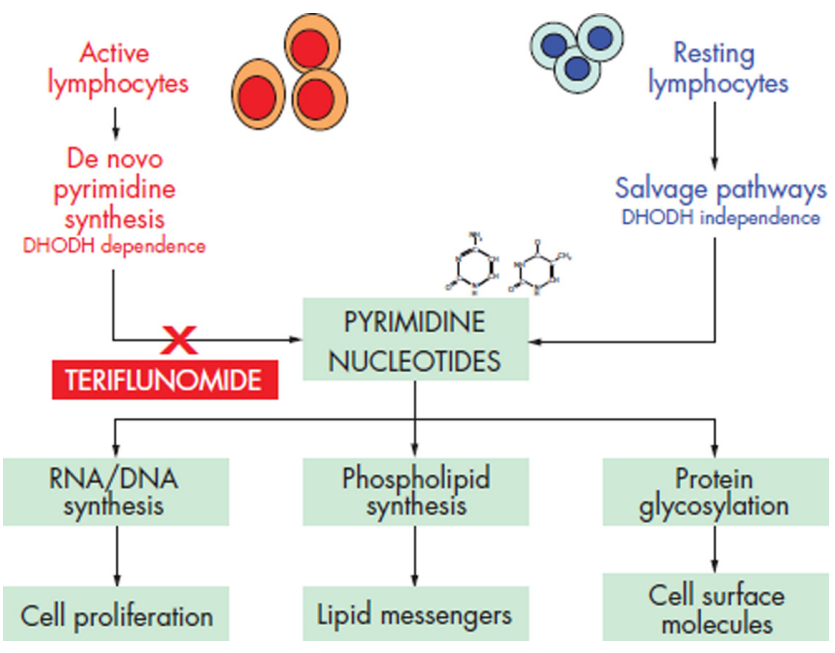

Figure 3 Mechanism of action of teriflunomide.

Note: Reprinted from Tallantyre et al. Spotlight on Teriflunomide. The International MS Journal. 2008; I5(2):62-68 with permission from Cambridge Medical Publications (CMP). 
effects of teriflunomide. ${ }^{27}$ Certain effects, however, remain inhibited - these will be discussed in further detail below.

\section{Inhibition of protein tyrosine kinases}

It was observed that the inhibitory effects of teriflunomide on certain lymphocyte activities such as cell migration, surface molecule expression, and cytokine production persist despite exogenous pyrimidine administration. ${ }^{33,35}$ These findings prompted further investigation of other potential molecular targets of teriflunomide. In vitro experiments in murine cell lines have shown that teriflunomide inhibits protein tyrosine-kinase (PTK) activity via inhibition of interleukin 2(IL-2)-induced tyrosine phosphorylation. ${ }^{36-38}$ Specifically, teriflunomide inhibits the janus tyrosine kinases jak1 and jak3 in an IL-2 dependent murine cytotoxic T cell line. Several effects result from the inhibition of PTK activity including reduced T-cell proliferation, reduced production of IL-2, inhibition of calcium mobilization, and a blockage of immunoglobulin G1 production. ${ }^{33,35,39}$ These effects have been shown to be independent of pyrimidine inhibition and to be not reversed by exogenous pyrimidine administration. Despite these findings, it is estimated that teriflunomide has 150- to 900 -fold more potent in vitro inhibition of DHODH compared to tyrosine kinases and it is doubtful that teriflunomide reaches in vivo concentrations high enough to exert clinically significant effects of PTK inhibition..$^{40,41}$ However, as rodent $\mathrm{T}$ cells are remarkably sensitive to the effects of DHODH inhibition, it could be suggested that both DHODH and PTK inhibition may be clinically significant in humans at therapeutic teriflunomide concentrations ${ }^{41}$ Regardless, it is clear that DHODH inhibition remains the principal mechanism of action of teriflunomide.

\section{Effects on $B$ and $T$ cells}

Teriflunomide inhibits T- and B-cell proliferation; however, more is known of its effect on T cells than that on B cells. Although the $\mathrm{IC}_{50}$ for inhibition of cell proliferation is lower in B-cell compared to T-cell cultures, primary splenic mitogen-activated $\mathrm{T}$ cells and $\mathrm{B}$ cells have both been proven to be equally susceptible to teriflunomide. ${ }^{42}$ Teriflunomide has also demonstrated efficiency in inhibiting T-cell-dependent antibody production, suggesting that it modulates the interaction between T cells and B cells. ${ }^{43}$ Direct T-cell inhibitory effects include the alteration of integrin function (at different stages of T-cell activation) and interference with calcium signaling to $\mathrm{T}$ cells. These inhibitory actions of teriflunomide lead to several results which include a diminished interaction between $T$ cells and antigen-presenting cells, an impaired migratory capability of T cells (in vitro and in vivo), and a diminished ability for exposed $\mathrm{T}$ cells to activate monocytes in vitro. ${ }^{30,37,41,44}$ Teriflunomide also appears to induce naïve $\mathrm{T}$ cells to favor Th- 2 differentiation. A bias towards Th-2 differentiation after exposure to teriflunomide was demonstrated in naïve human precursor cells from peripheral blood, and in antigen-specific $\mathrm{T}$ cells in mice. ${ }^{45} \mathrm{In}$ vitro exposure of T cells to teriflunomide triggered an increase in the production of the anti-inflammatory compounds named IL-1 receptor antagonists and tissue inhibitor of metalloproteinase-1 without an increase in their proinflammatory counterparts IL-1B and matrix metalloproteinase- $1 .^{44}$ In rodent antigen-experienced T cells and microglia, exposure to teriflunomide caused inhibition of IFN- $\gamma$-producing T cells while stimulating IL-10- and IL-4-producing T cells. In addition, the cytokine signature of microglial cells and macrophages is modulated by teriflunomide to favor-enhanced secretion of IL-10. ${ }^{37}$

\section{Other effects}

Teriflunomide has demonstrated cyclooxygenase-2 (COX-2) inhibitory activity in murine macrophage cell lines. Specifically, teriflunomide inhibited the formation of prostaglandin E2, an enzymatic product of COX-2. In vitro inhibition of COX-2 required teriflunomide concentrations at least ten times greater than the concentrations necessary for DHODH inhibition. In addition, the COX-2 inhibition was reversed by high levels of arachidonic acid. ${ }^{46}$ These two aspects suggest that any meaningful clinical effects of COX-2 inhibition by teriflunomide are limited.

In murine macrophages, teriflunomide caused downregulation of inducible nitric oxide synthase but failed to effect a reduction in inducible nitric oxide synthase activity. In contrast, such a reduction was demonstrated in a study on murine astrocytes..$^{47,48}$

The effects of DHODH inhibition also extend to myeloid cell lines via the suppression of growth factor-induced proliferation in myeloid progenitors and mast cell lines. ${ }^{43}$ In vitro suppression of myeloid progenitors by teriflunomide occurs at very low concentrations. Certain effector functions of the innate immune system are also suppressed by teriflunomide. These include modulated expression of adhesion molecules, adherence, and migration of neutrophils and macrophages. ${ }^{49,50}$

\section{Pharmacokinetics of teriflunomide}

The pharmacokinetic (PK) profile of teriflunomide is based primarily on eleven studies in healthy humans; only a single PK study in MS patients has been conducted. ${ }^{51}$ Teriflunomide doses used in studies ranged from $7 \mathrm{mg}$ to $100 \mathrm{mg}$. In fasting, 
healthy subjects given single oral doses, the median time to peak plasma concentration was 1 to 2 hours. Teriflunomide oral bioavailability approximates $100 \%$ although delayed absorption was demonstrated with drug administration in fed subjects; however, plasma concentrations were similar in both fasting and fed states. Peak plasma concentrations were dose proportional, indicating that teriflunomide possesses linear PK properties. The drug is highly bound to plasma proteins $(>99 \%)$ but has a very low volume of distribution at steady state $(\sim 11 \mathrm{~L})$. Teriflunomide has an extended elimination half-life which ranges from 10 to 18 days.

Phase I metabolism of teriflunomide involves $\mathrm{CYP}_{450} 3 \mathrm{~A}$ enzymes. It would be expected that $\mathrm{CYP}_{450} 3 \mathrm{~A}$ inducers would accelerate the metabolism of teriflunomide and a study in healthy subjects showed an area under the curve decrease of approximately 39\% when teriflunomide was administered concurrently with the potent non-specific cytochrome P450inducer rifampicin. ${ }^{52}$ Teriflunomide is also a cytochrome $\mathrm{P} 450$ 2C9 inhibitor and would be expected to prolong the effects of cytochrome P450 2C9 substrates including warfarin, but data regarding possible drug interactions are lacking. In PK studies of healthy volunteers, $37.5 \%$ of teriflunomide was primarily excreted into feces (as unchanged drug), and 22.6\% through the urine as the 4-trifluoro-methylaniline oxanilic acid metabolite. ${ }^{51}$ Teriflunomide has a very slow plasma clearance (approximately $0.05 \mathrm{~L} /$ hour $){ }^{52}$ which is attributable to extensive enterohepatic recycling of the drug. Like its parent drug leflunomide, elimination can be hastened by administration of medications such as charcoal or cholestyramine which inhibit enterohepatic recycling. Its reversibility may provide teriflunomide with an advantage over other oral agents for MS. No differences in the PK profile of teriflunomide were found according to age, gender, or hepatic impairment. Based on limited data, the PK profile of teriflunomide in patients with MS appears to be similar to that determined in healthy subjects. ${ }^{51}$

\section{Clinical studies of teriflunomide in MS}

Teriflunomide has been studied both as monotherapy and in combination with typical disease-modifying therapies (DMTs) in patients with MS. To date, clinical results are available from several smaller Phase II trials and two large Phase III trials. Other large Phase III trials are ongoing (Table 1).

\section{Use as monotherapy}

A randomized, double-blind, placebo-controlled Phase II study of teriflunomide was conducted in patients with clinically confirmed MS. ${ }^{53}$ The majority of the study subjects had RRMS ( $\mathrm{n}=157)$ and a smaller number enrolled had SPMS $(n=22)$. Teriflunomide loading doses of twice the maintenance doses were used for 1 week after which patients received standard maintenance doses of $7 \mathrm{mg}$ or $14 \mathrm{mg}$ given once daily. Patient inclusion criteria consisted of an expanded disability status scale (EDSS) score of $\leq 6$, two documented relapses in the previous 3 years, and one clinical relapse during the preceding year. Exclusion criteria included prior treatment with interferon (IFN), gamma-globulin, glatiramer acetate, or other non-corticosteroid immunomodulatory therapies in the 4-week period prior to initiation of teriflunomide. Use of effective contraception methods was required for both men and women during the trial period; at study conclusion, patients had the option to either continue effective contraception for a further 24 months, or undergo a teriflunomide washout procedure. The primary endpoint of the study was the composite number of new or expanding gadolinium-enhancing T1 (T1-Gd) lesions and T2 lesions which was termed the number of combined unique active lesions (CUALs) per MRI scan. If a lesion had both T1 and T2 properties, it was counted as a single lesion. Secondary endpoints included MRI-defined disease burden (total area/ volume of T2 lesions on MRI), MS relapse frequency, and an increase in disability scores (defined as a 1-point EDSS increase if the baseline EDSS was $<5.5$ or a 0.5 -point increase if the baseline EDSS was $\geq 5.5$ ).

Teriflunomide proved efficacious in significantly decreasing the CUALs in patient groups treated with either dose. The annualized relapse rates (ARRs) were lower in each treatment group and a trend toward fewer relapses was seen in the 14-mg-per-day group. Although the ARRs did not reach significance, it is important to note that the study was not sufficiently powered to analyze this secondary endpoint. In addition to a lower ARR, the beneficial effects of teriflunomide in this study appeared to favor the higher $14 \mathrm{mg}$ daily dose when the outcomes of EDSS scores and change over time in T2 lesion volume were considered. ${ }^{53}$ A total of 19 patients discontinued study medication prematurely during the 36-week treatment period, with the $14 \mathrm{mg}$ per day group having the greatest number of discontinuations. Withdrawal due to treatment-emergent adverse events (TEAEs) occurred in 15 of the 19 patients, eight of whom were in the 14-mgdaily dose group.

In an open-label extension of the trial, patients previously on placebo were switched to either the 7-mg-daily dose or the 14-mg-daily dose. Efficacy data in patients who 
Table I Clinical trial summaries for teriflunomide (TERI)

\begin{tabular}{|c|c|c|c|c|c|}
\hline Study & $\mathbf{n}$ & Subjects & Regimen & Duration & Outcomes \\
\hline $\begin{array}{l}\text { Phase } \|^{53} \\
\text { monotherapy }\end{array}$ & 179 & $\begin{array}{l}\text { RRMS } \\
\text { SPMS } \\
\text { mean age: } 40 \text { years } \\
74 \% \text { female } \\
\text { mean EDSS: } 2.3\end{array}$ & $\begin{array}{l}\text { TERI } 7 \text { mg/day } \\
\text { TERI } 14 \text { mg/day } \\
\text { PBO }\end{array}$ & 36 weeks & $\begin{array}{l}\text { MRI: } 6 I \% \text { RR of CUALs (TI-Gd,T2) } \\
\text { in both treatment groups vs PBO } \\
\text { ( } 7 \mathrm{mg}, P<0.03 ; 14 \mathrm{mg}, P<0.0 \mathrm{I}) \\
\text { Clinical: ARR lower in both treatment } \\
\text { groups vs PBO (mean } \pm \text { SD } 0.58 \pm 0.85 \\
\text { and } 0.55 \pm 1.13 \text { vs } 0.8 \mathrm{I} \pm 1.22 \text {; NS) } \\
\text { - Trend toward lower annualized relapse } \\
\text { rate (32\%) and fewer relapsing patients } \\
\text { in I4-mg-daily group versus placebo (NS) } \\
\text { Adverse events: } \\
\text { - TEAEs more common in TERI groups } \\
\text { ( } \geq 10 \% \text { of patients): HA, alopecia, } \\
\text { nausea, ALT, paresthesia, back } \\
\text { and limb pain, diarrhea, arthralgia }\end{array}$ \\
\hline $\begin{array}{l}\text { Open-label } \\
\text { extension } \\
\text { of Phase II } \\
\text { trial }^{54}\end{array}$ & 147 & $\begin{array}{l}\text { RRMS } \\
\text { SPMS }\end{array}$ & $\begin{array}{l}\text { PBO-7 mg switch } \\
\text { PBO-14 mg switch } \\
\text { Continuous } 7 \text { mg } \\
\text { Continuous } 14 \text { mg }\end{array}$ & I 44 weeks & $\begin{array}{l}\text { MRI: significant } \downarrow \text { in number of CUALs } \\
\text { (RRR } 65 \% \text { and } 85 \% \text { for } 7 \mathrm{mg} \text { and } \\
\text { I4 mg, respectively, } P=0.02 \text { ) } \\
\text { in PBO-switch groups } \\
\text { Patients previously on TERI experienced } \\
\text { no further change in number } \\
\text { of active lesions } \\
\text { Clinical: ARRs } 0.4 \text { per year in all groups; } \\
\text { proportion of relapse-free patients } \\
\text { at week I } 44=54 \% \\
\text { - EDSS scores similar among groups } \\
\text { Adverse events: similar events } \\
\text { and frequencies in groups }\end{array}$ \\
\hline $\begin{array}{l}\text { Phase II } \\
\text { combination } \\
\text { therapy }{ }^{57}\end{array}$ & 123 & Relapsing MS & $\begin{array}{l}\text { TERI } 7 \text { mg/day + } \\
\text { GA (stable dose) } \\
\text { TERI I } 4 \text { mg/day + } \\
\text { GA (stable dose) } \\
\text { PBO + } \\
\text { GA (stable dose) }\end{array}$ & 24 weeks & $\begin{array}{l}\text { MRI: TI-Gd lesions } \downarrow \text { in } 7 \mathrm{mg} \\
(P=0.0 \mathrm{II}) \text { and I } 4 \mathrm{mg} \text { groups }(P=0.039) \\
\text { compared to PBO } \\
\text { Adverse events: } \\
\text { - ALT }>3 \times \text { ULN: one in PBO } \\
\text { and one in I } 4 \mathrm{mg} \text { group } \\
\text { - Immunosuppression/infection: similar } \\
\text { in all groups (PBO: } 44 \%, 7 \mathrm{mg}: 43 \% \text {, } \\
\text { I4 mg: } 38 \%)\end{array}$ \\
\hline $\begin{array}{l}\text { Phase II } \\
\text { combination } \\
\text { therapy }{ }^{58}\end{array}$ & 117 & $\begin{array}{l}\text { Relapsing MS } \\
\text { mean age: } 40 \text { years } \\
70 \% \text { female } \\
\text { mean EDSS: } 2.5\end{array}$ & $\begin{array}{l}\text { TERI } 7 \text { mg/day + } \\
\text { IFN- } \beta \text { I a (stable dose) } \\
\text { TERI I } 4 \text { mg/day + } \\
\text { IFN- } \beta \text { I a (stable dose) } \\
\text { PBO + IFN- } \beta \text { I a (stable } \\
\text { dose) }\end{array}$ & 24 weeks & 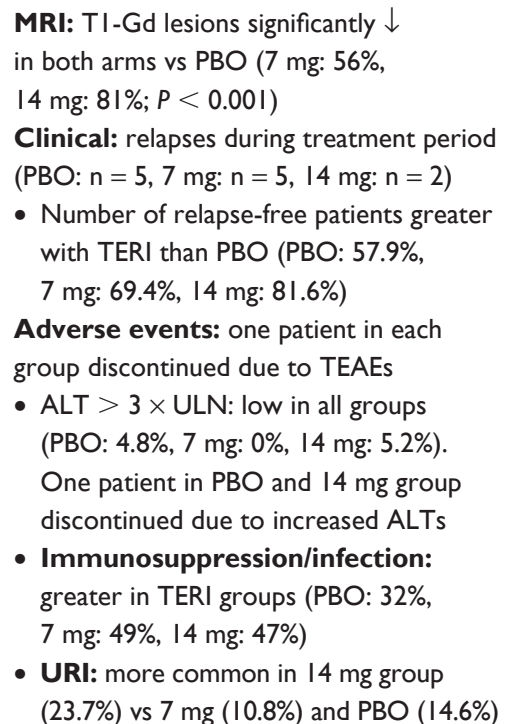 \\
\hline
\end{tabular}


Table I (Continued)

\begin{tabular}{|c|c|c|c|c|c|}
\hline Study & $\mathbf{n}$ & Subjects & Regimen & Duration & Outcomes \\
\hline $\begin{array}{l}\text { TEMSO } \\
\text { Phase III } 55,56\end{array}$ & 1088 & $\begin{array}{l}\text { RRMS } \\
\text { SPMS } \\
\text { mean age: } 37.8 \text { years } \\
72 \% \text { female } \\
\text { mean EDSS: } 2.68\end{array}$ & $\begin{array}{l}\text { TERI } 7 \text { mg/day } \\
\text { TERI } 14 \text { mg/day } \\
\text { PBO }\end{array}$ & 108 weeks & 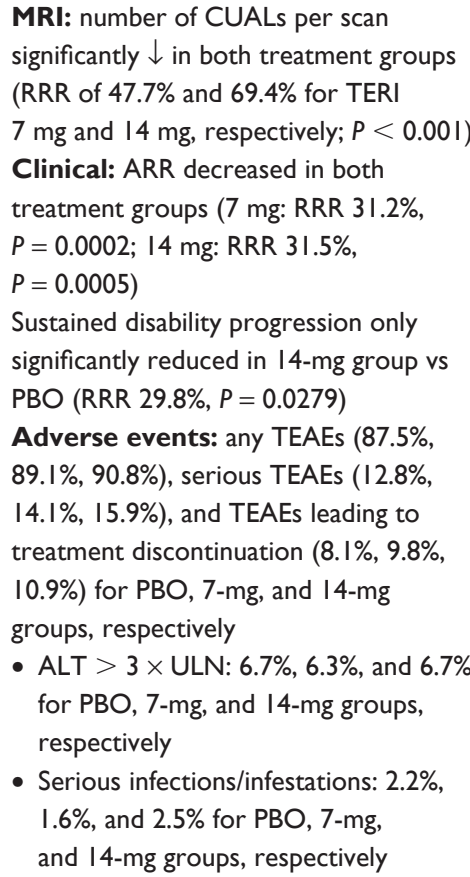 \\
\hline $\begin{array}{l}\text { TEMSO } \\
\text { open-label } \\
\text { extension }^{55,56}\end{array}$ & 556 & $\begin{array}{l}\text { RRMS } \\
\text { SPMS }\end{array}$ & $\begin{array}{l}\text { Active treatment } \\
\text { groups }\end{array}$ & $\geq 108$ weeks & $\begin{array}{l}\text { Ongoing extension study } \\
\text { Primary endpoint: safety/tolerability } \\
\text { Secondary endpoints: EDSS, ARR, MRI }\end{array}$ \\
\hline $\begin{array}{l}\text { TENERE } \\
\text { Phase } 1 I^{59}\end{array}$ & 324 & Relapsing MS & $\begin{array}{l}\text { TERI } 7 \text { mg/day } \\
\text { TERI I } 4 \text { mg/day } \\
\text { IFN- } \beta \text { I a } 44 \mu g \text { tiw }\end{array}$ & 48 weeks & $\begin{array}{l}\text { Clinical: time to treatment failure } \\
\text { similar between the } 7-\mathrm{mg}(48.6 \%) \text {, } \\
\text { I4-mg ( } 37.8 \%) \text {, and IFN- } \beta \text { I a }(42.3 \%) \\
\text { groups } \\
\text { - ARR similar between the I4-mg } \\
\text { and IFN- } \beta \text { I a groups ( } 25.9 \% \text { vs } 21.6 \%) \\
\text { but higher in the } 7 \text {-mg group ( } 4 \text { I } \%) \\
\text { Adverse events most common with } \\
\text { TERI: nasopharyngitis, diarrhea, hair } \\
\text { thinning, back pain } \\
\text { Treatment discontinued due to TEAEs: } \\
7 \text { mg ( } 8.2 \%), ~ I 4 \text { mg (I0.9\%), IFN- } \beta \text { Ia } \\
\text { ( } 21.8 \%)\end{array}$ \\
\hline $\begin{array}{l}\text { TOWER }^{\mathrm{a}} \\
\text { Phase III }\end{array}$ & $1110 *$ & Relapsing MS & $\begin{array}{l}\text { TERI } 7 \text { mg/day } \\
\text { TERI I } 4 \text { mg/day } \\
\text { PBO }\end{array}$ & $\geq 48$ weeks & $\begin{array}{l}\text { Ongoing } \\
\text { Primary endpoint: ARR } \\
\text { Secondary endpoint: disability } \\
\text { progression }\end{array}$ \\
\hline $\begin{array}{l}\text { TOPIC }^{\text {a }} \\
\text { Phase III }\end{array}$ & $780 *$ & $\mathrm{CIS}$ & $\begin{array}{l}\text { TERI } 7 \text { mg/day } \\
\text { TERI } 14 \text { mg/day } \\
\text { PBO }\end{array}$ & 2 years & $\begin{array}{l}\text { Ongoing } \\
\text { Primary endpoint: conversion of CIS } \\
\text { to clinically definite MS } \\
\text { Secondary endpoint: ARR, MRI, disability } \\
\text { progression, safety and tolerability }\end{array}$ \\
\hline $\begin{array}{l}\text { TERACLES } \\
\text { Phase III }\end{array}$ & $1455^{*}$ & Relapsing MS & $\begin{array}{l}\text { TERI } 7 \text { mg/day + } \\
\text { IFN- } \beta \text { Ia (stable dose) } \\
\text { TERI I } 4 \text { mg/day + } \\
\text { IFN- } \beta \text { Ia (stable dose) } \\
\text { PBO + IFN- } \beta \text { Ia } \\
\text { (stable dose) }\end{array}$ & 48-I52 weeks & $\begin{array}{l}\text { Ongoing } \\
\text { Primary endpoint: ARR } \\
\text { Secondary endpoint: MRI, EDSS, } \\
\text { change in abnormal brain volume }\end{array}$ \\
\hline
\end{tabular}

Notes: aData on ongoing trials obtained from ClinicalTrials.gov, accessed September 29, 20II. *Planned recruitment total.

Abbreviations: ALT, alanine aminotransferase; ARR, annual relapse rates; CIS, clinically isolated syndrome; CUALs, cumulative active lesions; EDSS, expanded disability status scale; GA, glatiramer acetate; HA, headache; IFN, interferon; MRI, magnetic resonance imaging; NS, nonsignificant; PBO, placebo; RR, relative reduction; RRMS, relapse remitting multiple sclerosis; RRR, relative risk reduction; SPMS, secondary progressive multiple sclerosis; TI-Gd, gadolinium enhancing; TEAEs, treatment emergent adverse events; TERI, teriflunomide; tiw, three times a week; ULN, upper limit of normal; URI, upper respiratory infection. 
completed 144 weeks of therapy demonstrated a decrease in CUALs when compared to baseline values at the start of the extension trial. This decrease was found in both treatment groups, with the greater CUALs decrease seen in the 14-mg-per-day group. Patients receiving 7- or 14-mg teriflunomide daily regimens in the original study experienced no further decreases in CUALs during the extension phase. The incidence of elevated liver enzymes greater than three times the upper limit of normal $(>3 \times \mathrm{ULN})$ was reported to be uncommon and not dose related. ${ }^{54}$ This is in contrast to leflunomide which has been reported to cause significant hepatotoxicity. The overall dropout rate in this teriflunomide extension study was $<10 \%$ per year.

A randomized, double-blind, placebo-controlled Phase III trial-Teriflunomide Multiple Sclerosis Oral (TEMSO) - that evaluated teriflunomide in patients with RRMS or SPMS with relapses was recently completed. To be included in the study, patients had to have EDSS scores of $\leq 5.5$ and at least one relapse during the previous year, or two relapses in the preceding 2 years. Exclusion criteria included patients with other clinically relevant systemic diseases, pregnancy, or a plan for conception during the trial period. Patients on other immunosuppressant agents were also excluded. Teriflunomide $7 \mathrm{mg}$ or $14 \mathrm{mg}$ daily was compared to placebo and patients were treated for 108 weeks. The primary endpoint was ARR and secondary endpoints included time to confirmed disability progression per EDSS score and CUALs per MRI scan.

Both teriflunomide dosages were significantly more effective than placebo in the primary outcome of ARR. Active drug treatment at either dosage also was associated with significant decreases in CUALs but a significant effect on sustained disability progression was observed only in the 14-mg-per-day group. Discontinuation in the trial due to TEAEs occurred at similar rates in all groups with $73.2 \%$ of patients completing study treatment. An open-label extension study of TEMSO is currently ongoing ${ }^{55,56}$ as is a second trial - TOWER - which is also evaluating the 7-mg and 14-mg-daily doses of teriflunomide versus placebo.

\section{Use in combination therapy}

Teriflunomide as adjunctive therapy combined with glatiramer acetate (GA) was evaluated in a small Phase II trial with 123 patients. The number of patients with baseline T1-Gd lesions was greater in the 7-mg-per-day cohort $(28.6 \%)$ compared to the placebo (14.6\%) and 14-mg-per-day groups (12.8\%); all other baseline characteristics were similar. Teriflunomide at either dose added to GA was more effective than placebo added to GA in reducing T1-Gd lesions. Seven patients in the treatment groups (three patients in the 7-mgper-day and four patients in the 14-mg-per-day group) discontinued study drug; however, no patients discontinued the study due to increased liver enzymes or infection. No deaths were reported in the study. ${ }^{57}$

Results of a small double-blind, placebo-controlled Phase II study of teriflunomide as adjunctive therapy with IFN- $\beta$ were presented at the European Committee for Treatment and Research in Multiple Sclerosis (ECTRIMS) meeting in 2009. The study included 117 patients with relapsing MS already on a stable dose of IFN- $\beta$. Approximately one third of patients were on low-dose IFN- $\beta 1 \mathrm{a}-30 \mu \mathrm{g}$ intramuscularly once weekly or $22 \mu \mathrm{g}$ subcutaneously three times weekly. The other groups of patients were receiving highdose, high-frequency IFN- $\beta 1 \mathrm{a}$ (44 $\mu \mathrm{g}$ subcutaneously three times weekly) or IFN- $\beta 1 \mathrm{~b}$ ( $250 \mu \mathrm{g}$ subcutaneously every other day). Teriflunomide $7 \mathrm{mg}$ or $14 \mathrm{mg}$ daily or placebo was added to the interferon-based treatment for 24 weeks. The mean baseline EDSS score for all patients was 2.5 and $40 \%$ of patients had not relapsed in the previous year. The primary endpoint was the number of T1-Gd active lesions. The number of lesions was significantly decreased in both teriflunomide treatment groups when compared to the group receiving IFN- $\beta$ alone. The teriflunomide 14-mg-per-day group demonstrated the greatest efficacy but also had the highest incidence of TEAEs. ${ }^{58}$ One patient in each group discontinued prematurely due to TEAEs. Although collected by study authors, details on EDSS score changes were not reported; however, a significant change would not be expected due to the short duration of the trial.

The preliminary results of a Phase III trial (TENERE) comparing the safety and efficacy of teriflunomide and IFN$\beta 1 \mathrm{a}$ in patients with relapsing forms of MS were recently released. The study consisted of 324 patients randomized to either daily doses of teriflunomide $7 \mathrm{mg}(\mathrm{n}=109)$ or $14 \mathrm{mg}$ $(\mathrm{n}=111)$, or IFN- $\beta 1 \mathrm{a} 44 \mu \mathrm{g}$ three times weekly $(\mathrm{n}=104)$ and followed for 48 weeks. Patients 18 years or older with an EDSS of 5.5 or less at the initial screening visit were included in the study. The primary endpoint was risk of treatment failure which was defined as the occurrence of a confirmed relapse or permanent treatment discontinuation for any cause, whichever came first. The primary endpoint occurred at a similar rate among treatment groups. The secondary endpoint was the ARR. The 14-mg-per-day teriflunomide and IFN- $\beta 1$ a groups had a similar ARR (25.9\% vs $21.9 \%$ ) but ARR was higher in the teriflunomide 7-mg-daily group (41\%). Similar to previous studies, common TEAEs in the teriflunomide arm included 
nasopharyngitis, diarrhea, hair thinning, and back pain. However, the incidence of elevated liver enzymes, headache, and flu-like symptoms was higher in the IFN- $\beta 1$ a group. Treatment discontinuations due to TEAEs were also lowest in the teriflunomide groups. No deaths were reported in this study. ${ }^{59}$ A Phase III trial comparing teriflunomide as adjunctive therapy

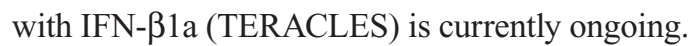

\section{Safety and tolerability of teriflunomide}

As previously stated, adverse events in teriflunomide trials typically occurred to an equal degree across all treatment and placebo groups (Table 2). In the Phase II trial of teriflunomide monotherapy, a decrease in leukocytes was seen more frequently in the active drug groups but infection rates were similar among treatment and placebo groups and there were no discontinuations of therapy owing to leukopenia. ${ }^{53}$ In contrast, a higher rate of infections in the teriflunomide treatment groups was seen when the drug was combined with IFN- $\beta 1$ a, an effect that interestingly was not seen in combination therapy with glatiramer acetate.

Teriflunomide does appear to elevate alanine aminotransferase to a greater degree than placebo. However, the incidence of clinically significant elevations in hepatic transaminases $(>3 \times \mathrm{ULN})$ due to teriflunomide was similar to that in placebo groups in both the Phase II trial and TEMSO. Data from the 144-week open-label extension of the Phase II trial further demonstrated that the effect of teriflunomide on alanine aminotransferases remained stable. ${ }^{53-56}$

Discontinuation rates were low in both the monotherapy and combination therapy trials of teriflunomide. The teriflunomide 14-mg-per-day group in the Phase II monotherapy trial had the greatest number of discontinuations (19\% vs $3 \%$ and $6.5 \%$ in the $7-\mathrm{mg}$-per-day and placebo groups, respectively); however, this was not seen in other trials. Based on trial

Table 2 Incidence of the most common adverse events in Phase II and Phase III teriflunomide trials ${ }^{53-59}$

\begin{tabular}{ll}
\hline Adverse event & Incidence (\%) \\
\hline ALT increase & $12-14.2$ \\
Headache & $19-25$ \\
Nasopharyngitis & $21-26$ \\
Diarrhea & $8-17.9$ \\
Fatigue & $10-14.5$ \\
Nausea & $9-13.7$ \\
Alopecia & $12-15$ \\
UTI & $7.3-11$ \\
Back or limb pain & $7-14$ \\
\hline
\end{tabular}

Abbreviations: ALT, alanine aminotransferase; UTI, urinary tract infection. results, a higher adverse event and discontinuation rate may be expected in patients taking the higher dose of teriflunomide. In addition, morbidity of teriflunomide appears low and no deaths were reported in any of the studies.

Long-term safety data from leflunomide will almost certainly be used to supplement the safety data from teriflunomide studies and will likely affect recommendations regarding its use. Due to reports of severe liver injury, leflunomide use requires liver function tests prior to initiating therapy, and then monthly for the first 6 months of treatment, then every 6 to 8 weeks thereafter. ${ }^{60}$ There has been one documented case of progressive multifocal leukoencephalopathy in a patient with systemic lupus erythematous receiving leflunomide. ${ }^{61}$ This case was complicated by the fact that the patient had already been on several immunosuppressive drugs including prednisone, azathioprine, chloroquine, danazol, cyclosporine A, and finally, methotrexate. No data exists linking teriflunomide use with progressive multifocal leukoencephalopathy.

In preclinical animal studies, leflunomide demonstrated some reproductive toxicity ${ }^{62}$ and it would be expected that teriflunomide also will have a "black box" warning against its use during pregnancy. However, interim data of pregnant patients with rheumatoid arthritis who were exposed to leflunomide early in pregnancy $(n=43)$ had similar outcomes compared with the control population $(n=47) .{ }^{53}$ A study of 64 pregnancies in women exposed to leflunomide observed no significant differences in the overall rate of structural birth defects compared to nonexposed pregnancies. ${ }^{63}$ Therefore, if accidental pregnancy does occur, termination of the pregnancy is not required. However, until its teratogenic profile is fully understood, it is recommended that women of childbearing age utilize effective methods of contraception. As expected, men and women not using adequate methods of contraception were excluded from teriflunomide studies. Study data did show that forms of contraception including oral contraceptives maintained their efficacy with concurrent teriflunomide coadministration, without affecting the drug's pharmacokinetic profile. As with leflunomide, women desiring pregnancy should undergo a "washout period" with either cholestyramine or activated charcoal after stopping treatment with teriflunomide. An 11-day course of cholestyramine $8 \mathrm{~g}$ three times daily is recommended as it has been shown to decrease the half-life of teriflunomide to approximately 24 hours. ${ }^{62}$ Due to the PK properties of teriflunomide and individual variations in drug clearance, it may take up to 2 years to reach safe plasma levels if the washout procedure is not instituted. ${ }^{52,53,62} \mathrm{~A}$ teriflunomide assay to confirm a plasma level of $<0.02 \mathrm{mg} / \mathrm{L}-$ in two separate tests 14 days apart - is recommended after the 
Table 3 Clinical aspects of newer oral disease-modifying therapies

\begin{tabular}{|c|c|c|c|c|c|c|}
\hline Agent & MOA & Major trials & ARR RR & MRI lesions RR & Dosing regimen & AE profile \\
\hline TER/ $\left.\right|^{53-59}$ & $\begin{array}{l}\text { Lymphocyte } \\
\text { anti-proliferation }\end{array}$ & $\begin{array}{l}\text { TEMSO,TENERE } \\
\text { TOPIC,TERACLES }\end{array}$ & $>30 \%$ & CUALs > $70 \%$ & Once daily & $\begin{array}{l}\uparrow \text { LFTs, neutropenia, } \\
\text { nasopharyngitis, alopecia, } \\
\text { nausea, paresthesia, } \\
\text { diarrhea, arthralgia, } \\
\text { back and limb pain }\end{array}$ \\
\hline Fingolimod ${ }^{72-74}$ & $\begin{array}{l}\text { Lymphocyte } \\
\text { sequestration }\end{array}$ & $\begin{array}{l}\text { FREEDOMS } \\
\text { TRANSFORMS }\end{array}$ & $>50 \%$ & $\begin{array}{l}\mathrm{Gd}^{+} \text {lesions } \\
>60 \%\end{array}$ & Once daily & $\begin{array}{l}\text { Lymphocytopenia, serious } \\
\text { viral infections, } \uparrow \text { LFTs, } \\
\text { bradycardia, AV block, } \\
\text { macular edema, cancers }\end{array}$ \\
\hline Laquinimod ${ }^{75-78}$ & Th1 toTh2 shift & ALLEGRO, BRAVO & $>20 \%$ & CUALs $40 \%$ & Once daily & $\begin{array}{l}\uparrow \text { LFTs, chest pain, back } \\
\text { pain, abdominal pain, viral } \\
\text { infections, menometorrhagia } \\
\text { with myofibroma, } \\
\text { exacerbation of preexisting } \\
\text { glaucoma }\end{array}$ \\
\hline Fumarate ${ }^{79,80}$ & $\begin{array}{l}\text { Activation of } \mathrm{Nrf2} \\
\text { pathway }\end{array}$ & DEFINE, CONFIRM & $>30 \%(\mathrm{NS})^{*}$ & $\begin{array}{l}\text { Gd+ lesions } \\
\sim 70 \%\end{array}$ & Three times daily & $\begin{array}{l}\text { Flushing, headache, nausea, } \\
\text { nasopharyngitis, pruritus, } \\
\uparrow \text { LFTs }\end{array}$ \\
\hline
\end{tabular}

Note: *Nonsignificant based on Phase II trial data, Phase III data pending.

Abbreviations: AE, adverse events; ARR, annual relapse rates; AV, atrioventricular; MRI, magnetic resonance imaging; CUALs, cumulative active lesions; Gd+, gadolinium positive; LFTs, liver function tests; MOA, mechanism of action; NS, nonsignificant; PBO, placebo; RR, relative reduction.

washout period as this level is suggested to present the least teratogenic risk based on available data. ${ }^{62}$

\section{Conclusion}

MS is similar to other chronic incurable diseases, in that it requires lifelong therapy. Until recently, all first-line DMT medications required parenteral administration. Long-term adherence with injections can be compromised due to injection-site adverse effects, needle phobia, or lifestyle disruptions inherent in parenteral therapy. ${ }^{64}$ Clinical trials typically attract highly motivated patients and discontinuation rates for injectable MS products have ranged from $9 \%-21 \%$ even during relatively short clinical trial periods of $1-2$ years. ${ }^{65}$ Several postmarketing studies assessing adherence with injectable MS drugs suggest there are even greater rates of interrupted or discontinued therapy during typical clinical use compared to rates reported during clinical trials. ${ }^{66}$ Unrealistic expectations about drug efficacy, advancement in disease progression, and unrelenting adverse effects are important elements of nonadherence. ${ }^{67}$ MS comorbidities of anxiety, depression, memory, and executive function impairments are additional factors that can affect adherence. One prospective adherence study in MS patients indicated that over $60 \%$ of MS patients with mood or anxiety disorders experienced poor or variable adherence. ${ }^{68}$

The arrival of oral medications for treatment of MS has been a long-anticipated event because of the belief that these products would translate into better adherence. ${ }^{69}$
Oral medication options alleviate the obvious barriers to compliance associated with parenteral injection techniques. However, when compared to parenteral therapy, ease of administration of oral products alleviates only a single factor affecting adherence. Parenteral MS therapies have a long history of efficacy and a well-defined risk profile. To replace parenteral therapies any new MS agent would likely need to demonstrate comparable or improved efficacy, produce less frequent or severe adverse effects, and be offered at comparable or lower cost.

Monotherapy with teriflunomide during Phase II and Phase III trials has produced reductions in active brain lesions ${ }^{70}$ and reductions in ARR similar to existing parenteral monotherapy options, which is approximately $30 \%$. In a 6-month trial of teriflunomide used in combination with stable doses of IFN- $\beta 1$ a, approximately $70 \%-80 \%$ of patients were relapse free compared to about $60 \%$ of patients receiving IFN- $\beta 1$ a alone. ${ }^{58}$ Decreases in appearance of new or expanding lesions are also similar to those associated with the existing parenteral products. Finally, serious adverse effects due to teriflunomide in Phase II and Phase III trials have been relatively infrequent and no life-threatening adverse events have emerged to date. TEAEs led to teriflunomide discontinuation rates in less than $11 \%$ of patients in the TEMSO trial compared to withdrawal of $8.1 \%$ in the placebo arm, suggesting teriflunomide as monotherapy is overall well tolerated.

The degree of interest in new MS products and clinical trial results suggests that the optimal agent is not currently 
available. Fingolimod $\left(\right.$ Gilenya $\left.^{\circledR}\right)$ recently gained United States Food and Drug Administration and European approval. Major ongoing trials are in early clinical testing phases for alemtuzumab, fumarate, and laquinimod. However, much of the data should be considered preliminary since complete Phase III trial data is not available. A review of the findings from these trials is beyond the scope of this paper but a summary of the major trial outcomes is provided in Table 3. Oral cladribine is not included in Table 3 due to the fact that it was denied approval by the European Medicines Agency and the United States Food and Drug Administration (FDA) in 2010 and 2011, respectively. Merck Serono announced that they would no longer seek approval for oral cladribine for the treatment of MS. ${ }^{71}$ No direct comparative trials between teriflunomide and the other new oral agents exist. Should all the oral DMTs eventually gain regulatory approval, choices among the oral DMTs will depend on clinician preference, convenience of dosing schedules, adverse-event profiles, cost, and other salient factors.

Three major ongoing teriflunomide clinical trials, TOWER, TOPIC, and TERACLES, have yet to be completed. Each of these trials is tracking endpoints of critical interest to the MS community, including disability progression in the TOWER and TERACLES trials, and the conversion rate from CIS to CDMS in the TOPIC trial. Results from each of these studies should provide data that will help patients and physicians determine whether or not teriflunomide will provide significant advantages over currently used therapies. These trial results will also help determine if teriflunomide will emerge as a preferred therapy or if it will join the growing ranks of alternative disease-modifying therapies that provide significant but modest benefits.

\section{Disclosure}

The authors report no conflicts of interest in this work.

\section{References}

1. Noseworthy J, Lucchinetti C, Rodriguez M, Weinshenker BG. Multiple Sclerosis. N Engl J Med. 2000;343:938-952.

2. Pugliatti M, Sotgiu S, Rosati G. The worldwide prevalence of multiple sclerosis. Clin Neurol Neurosurg. 2002;104:182-191.

3. Rosati G. The prevalence of multiple sclerosis in the world: an update. Neurol Sci. 2001;22:117-139.

4. Duquette P, Murray TJ, Pleines J, et al. Multiple sclerosis in childhood: clinical profile in 125 patients. $J$ Ped. 1987;111(3):359-363.

5. Ruet A, Deloire M, Ouallet JC, Molinier S, Brochet B. Predictive factors for multiple sclerosis in patients with clinically isolated spinal cord syndrome. Mult Scler. 2011;17(3):312-318.

6. Miller D, Barkhof F, Montalban X, Thompson A, Filippi M. Clinically isolated syndromes suggestive of multiple slcerosis, part 1: natural history, pathogenesis, diagnosis, and prognosis. Lancet Neurol. 2005;4:281-288.
7. Mowry EM, Pesic M, Grimes B, Deen SR, Bacchetti P, Waubant E. Clinical predictors of early second event in patients with clinically isolated syndrome. J Neurol. 2009;256:1061-1066.

8. Lebrun C, Bensa C, Deboverie M, et al; for Club Francophone de la Sclérose en Plaques. Association between clinical conversion to multiple sclerosis in radiologically isolated syndrome and magnetic resonance imaging, cerebrospinal fluid, and visual evoked potential: follow-up of 70 patients. Arch Neurol. 2009;66(7): 841-846.

9. Polman C, Reingold S, Banwell B, et al. Diagnostic criteria for multiple sclerosis: 2010 revisions to the McDonald criteria. Ann Neurol. 2011;69:292-302.

10. Scalfari A, Neuhaus A, Degenhardt A, et al. The natural history of multiple sclerosis, a geographically based study 10: relapses and long-term disability. Brain. 2010;133:1914-1929.

11. Disanto G, Berlanga AJ, Handel AE, et al. Heterogeneity in multiple sclerosis: scratching the surface of a complex disease. Autoimmune Dis. 2011, Article ID 932351, 12 pages, 2011. doi:10.4061/2011/932351. Available from: http://www.ncbi.nlm. nih.gov/pmc/articles/PMC3005811/?tool=pubmed. Accessed February 3, 2012.

12. Confavreux C, Vukusic S. Natural history of multiple sclerosis: a unifying concept. Brain. 2006;129:606-616.

13. Libbey JE, McCoy LL, Fujinami RS. Molecular mimicry in multiple sclerosis. Int Rev Neurobiol. 2007;79:127-147. Available from: http://www.sciencedirect.com/science/article/pii/S0074774207790062 Accessed February 3, 2012.

14. Nguyen MD, Julien JP, Rivest S. Innate immunity: the missing link in neuroprotection and neurodegeneration. Nat Rev Neurosci. 2002;3:216-227.

15. Chandran S, Hunt D, Joannides A, Zhao C, Compston A, Franklin RJM. Myelin repair: the role of stem and precursor cells in multiple sclerosis. Phil Trans R Soc B Biol Sci. 2008;363:171-183.

16. Fisniku LK, Brex PA, Altmann DR, et al. Disability and T2 MRI lesions: a 20-year follow-up of patients with relapse onset of multiple sclerosis. Brain. 2008;131:808-817.

17. Bermel RA, Bakshi R. The measurement and clinical relevance of brain atrophy in multiple sclerosis. Lancet Neurol. 2006;5:158-170.

18. Trapp BD, Peterson J, Ransohoff M, Rudick R, Mork S, Bo L. Axonal transection in the lesions of multiple sclerosis. N Engl J Med. 1998;338:278-285.

19. Brex PA, Ciccarelli O, O'Riordan JI, Sailer M, Thompson AJ, Miller DH. A longitudinal study of abnormalities on MRI and disability from multiple sclerosis. N Engl J Med. 2002;246:158-164.

20. Trapp BD, Nave KA. Multiple sclerosis: An immune or neurodegenerative disorder? Annu Rev Neurosci. 2008:31:247-269.

21. Stüve O. Knowns and unknowns in the future of multiple sclerosis treatment. J Neurol Sci. 2009;287 Suppl 1:S30-S36.

22. Lucchinetti C, Brück W, Parisi J, Scheithauer B, Rodriguez M, Lassman H. Heterogeneity of multiple sclerosis lesions: implications for the pathogenesis of demyelination. Ann Neurol. 2000;47:707-717.

23. Kasper LH, Shoemaker J. Multiple sclerosis immunology: the healthy immune system vs the MS immune system. Neurology. 2010;74 Suppl 1: S2-S8.

24. Dalakas MC. B cells as therapeutic targets in autoimmune neurological disorders. Nat Clin Pract Neurol. 2008;4(10):557-567.

25. Bruneau JM, Yea CM, Spinella-Jaegle S, et al. Purification of human dihydro-orotate dehydrogenase and its inhibition by A77 1726, the active metabolite of leflunomide. Biochem J. 1998;336(Pt 2):299-303.

26. Chen JJ, Jones ME. The cellular location of dihydroorotate dehydrogenase: relation to de novo biosynthesis of pyrimidines. Arch Biochem Biophys. 1976;176(1):82-90.

27. Cherwinski HM, Cohn RG, Cheung P, et al. The immunosuppressant leflunomide inhibits lymphocyte proliferation by inhibiting pyrimidine biosynthesis. J Pharmacol Exp Ther. 1995;275(2): 1043-1049. 
28. Ruckemann K, Fairbanks LD, Carrey EA, et al. Leflunomide inhibits pyrimidine de novo synthesis in mitogen-stimulated T-lymphocytes from healthy humans. J Biol Chem. 1998;273(34):21682-21691.

29. Siemasko KF, Chong AS, Williams JW, Brenner EG, Finnegan A. Regulation of B cell function by the immunosuppressive agent leflunomide. Transplantation. 1996;61(4):635-642.

30. Claussen MC, Korn T. Immune mechanisms of new therapeutic strategies in MS - teriflunomide. Clin Immunol. 2012;142(1):49-56.

31. Fox RI, Herman ML, Frangou CG, et al. Mechanism of action for leflunomide in rheumatoid arthritis. Clin Immunol. 1999;93(3):198-208.

32. Fairbanks LD, Bofill M, Ruckemann K, Simmonds HA. Importance of ribonucleotide availability to proliferating T-lymphocytes from healthy humans. Disproportionate expansion of pyrimidine pools and contrasting effects of de novo synthesis inhibitors. J Biol Chem. 1995;270(50):29682-29689.

33. Korn T, Magnus T, Toyka K, Jung S. Modulation of effector cell functions in experimental autoimmune encephalomyelitis by leflunomide mechanisms independent of pyrimidine depletion. J Leukoc Biol. 2004;76(5):950-960.

34. Gold R, Wolinsky JS. Pathophysiology of multiple sclerosis and the place of teriflunomide. Acta Neurol Scand. 2011;124(2):75-84.

35. Korn T, Toyka K, Hartung HP, Jung S. Suppression of experimental autoimmune neuritis by leflunomide. Brain. 2001;124(9):1791-1802.

36. Elder RT, Xu X, Williams JW, Gong H, Finnegan A, Chong AS. The immunosuppressive metabolite of leflunomide, A77 1726, affects murine T cells through two biochemical mechanisms. J Immunol. 1997;159(1)22-27.

37. Siemasko K, Chong AS, Jack HM, Gong H, Williams JW, Finnegan A Inhibition of JAK 3 and STAT 6 tyrosine phosphorylation by the immunosuppressive drug leflunomide leads to a block in IG1 production. J Immunol. 1998;160(4):1581-1588.

38. Gonzalez-Alvaro I, Ortiz AM, Dominguez-Jimenez C, Aragon-Bodi A, Diaz Sanchez B, Sanchez-Madrid F. Inhibition of tumor necrosis factor and IL-17 production by leflunomide involves the JAK/STAT pathway. Ann Rheum Dis. 2009;68(10):1644-1650.

39. Xu X, Williams JW, Gong H, Finnegan A, Chong AS. Two activities of the immunosuppressive metabolite of leflunomide, A77 1726. Inhibition of pyrimidine nucleotide synthesis and protein tyrosine phosphorylation. Biochem Pharmacol. 1996;52(4):527-534.

40. Hermann ML, Schleyerbach R, Kirschbaum BJ. Leflunomide: an immunomodulatory drug for the treatment of rheumatoid arthritis and other autoimmune diseases. Immunopharmacology. 2000;47(2-3):273-289.

41. Tallantyre E, Evangelou N, Constantinescu CS. Spotlight on teriflunomide. Int MS J. 2008;15(2):62-68.

42. Bartlett RR, Dimitrijevic M, Mattar T, et al. Leflunomide (HWA 486), a novel immunomodulating compound for the treatment of autoimmune disorders and reactions leading to transplantation rejection. Agents Actions. 1991;32(1-2):10-21.

43. Zeyda M, Poglitsch M, Geyeregger R, et al. Disruption of the interaction of $\mathrm{T}$ cells with antigen-presenting cells by the active leflunomide metabolite teriflunomide: involvement of impaired integrin activation and immunologic synapse formation. Arthritis Rheum. 2005;52(9):2730-2739.

44. Déage V, Burger D, Dayer JM. Exposure of T lymphocytes to leflunomide but not to dexamethasone favors the production by monocytic cells of interleukin-1 receptor antagonist and the tissueinhibitor of metalloproteinases-1 over that of interleukin-1 beta and metalloproteinases. Eur Cytokine Netw. 1998;9(4):663-668.

45. Dimitrova P, Skopenko A, Hermann ML, et al. Restriction of de novo pyrimidine biosynthesis inhibits Th1 cell activation and promotes Th2 cell differentiation. J Immunol. 2002;169(6):3392-3399.

46. Hamilton LC, Vojnovic I, Warner TD. A771726, the active metabolite of leflunomide, directly inhibits the activity of cyclo-oxygenase- 2 in vitro and in vivo in a substrate-sensitive manner. $\mathrm{Br} J$ Pharmacol. 1999;127(7):1589-1596.
47. Miljkovic D, Samardzic T, Mostarica Stojkovic M, Stosic-Grujicic S, Popadic D, Trajkovic V. Leflunomide inhibits activation of inducible nitric oxide synthase in rat astrocytes. Brain Res. 2001;889(1-2):331-338.

48. Jankovic V, Samardzic T, Stosic-Grujicic S, Popadic D, Trajkovic V. Cell-specific inhibition of inducible nitric oxide synthase activation by leflunomide. Cell Immunol. 2000;199(2):73-80.

49. Cutolo M, Sulli A, Ghiorzo P, Pizzorni C, Craviotto C, Villaggio B. Anti-inflammatory effects of leflunomide on cultured synovial macrophages from patients with rheumatoid arthritis. Ann Rheum Dis. 2003;62(4):297-302.

50. Kraan MC, de Koster BM, Elferink JG, Post WJ, Breedveld FC, Tak PP. Inhibition of neutrophil migration soon after initiation of treatment with leflunomide or methotrexate in patients with rheumatoid arthritis: findings in a prospective, randomized, double-blind clinical trial in fifteen patients. Arthritis Rheum. 2000;43(7):1488-1495.

51. Limsakun T, Menguy-Vacheron F. Pharmacokinetics of oral teriflunomide, a novel oral disease-modifying agent under investigation for the treatment of multiple sclerosis. Neurology. 2010;74:A415

52. Rozman B. Clinical pharmacokinetics of leflunomide. Clin Pharmacokinet. 2002;41(6):421-430.

53. O’Connor PW, Li D, Freedman MS, et al; for Teriflunomide Multiple Sclerosis Trial Group; British Columbia MS/MRI Research Group. A phase II study of the safety and efficacy of teriflunomide in multiple sclerosis with relapses. Neurology. 2006;66(6):894-900.

54. O'Connor PW, Freedman MS, Bar-Or A, Rice GP, Confavreux C, Traboulsee A. Oral teriflunomide is effective and well tolerated in multiple sclerosis with relapses: results of an open-label 144-week extension study. 22nd Congress of the European Committee for the Treatment and Research in Multiple Sclerosis. September 27-30, 2006, Madrid, Spain. Abstract September 28, 2006.

55. O’Connor P, Wolinsky J, Confavreux C, et al. A placebo-controlled phase III trial (TEMSO) of oral teriflunomide in relapsing multiple sclerosis: clinical efficacy and safety outcomes. Multiple Sclerosis. 2010;16 Supp1 10:S7-S39.

56. O'Connor P, Wolinsky JS, Confavreux C, et al; for TEMSO Trial Group. Randomized trial of oral teriflunomide for relapsing multiple sclerosis. N Engl J Med. 2011;365(14):1293-1303.

57. Freedman M, Wolinsky JS, Frangin GA, et al. Oral teriflunomide or placebo added to glatiramer acetate for 6 months in patients with relapsing multiple sclerosis: safety and efficacy results. Neurology. 2010;74(9):A293.

58. Freedman MS, Wolinsky JS, Byrnes WJ, et al. Oral teriflunomide or placebo added to interferon beta for months in patients with relapsing multiple sclerosis: safety and efficacy results. Mult Scler. 2009;15(9):S273. Poster 878.

59. Genzyme. Genzyme reports top-line results for TENERE study of oral Teriflunomide in relapsing multiple sclerosis [press release]. Cambridge, MA: Genzyme; 2011 [December 20]. Available from: http://www.businesswire com/news/genzyme/20111219006550/en. Accessed February 24, 2012.

60. Leflunomide [package insert]. Bridgewater, NJ; Sanofi-Aventis U.S. LLC; 2010.

61. Warnatz K, Peter HH, Schumacher M, et al. Infectious CNS disease as a differential diagnosis in systemic rheumatic disease: three case reports and a review of the literature. Ann Rheum Dis. 2003;2(1):50-57.

62. Brent RL. Teratogen update: reproductive risks of leflunomide (Arava); a pyrimidine synthesis inhibitor: counseling women taking lefunomide before or during pregnancy and men taking leflunomide who are contemplating fathering a child. Teratology. 2001;63(2):106-112.

63. Chamber CD, Johnson DL, Robinson LK, et al; for Organization of Teratology Information Specialists Collaborative Research Group. Birth outcomes in women who have taken leflunomide during pregnancy. Arthritis Rheum. 2010;62(5):1494-1503.

64. Patti F. Optimizing the benefit of multiple sclerosis therapy: the importance of treatment adherence. Patient Prefer Adherence. 2010;4:1-9 Published online February 4, 2010. PMCID: PMC2819898. 
65. Portaccio E, Zipoli V, Siracusa G, Sorbi S, Amato MP. Long-term adherence to interferon B therapy in relapsing-remitting multiple sclerosis. Eur Neurol. 2008;59:131-135. DOI: 10.1159/000111875.

66. O'Rourke KET, Hutchinson M. Stopping beta-interferon therapy in multiple sclerosis: an analysis of stopping patterns. Mult Scler. 2005; 11:46-50.

67. Tremlett HL, Ogel J. Interrupted therapy: stopping and switching of the $\beta$-interferons prescribed for MS. Neurology. 2003;61(4):551-554.

68. Bruce JM, Hancock LM, Arnett P, Lynch S. Treatment adherence in multiple sclerosis: association with emotional status, personality, and cognition. J Behav Med. 2010;33:219-227.

69. Carroll WM. Oral Therapy for multiple sclerosis - sea change or incremental step? N Engl J Med. 2010;326:456-458.

70. Palmer AM. Teriflunomide, an inhibitor of dihydroorotate dehydrogenase for the potential oral treatment of multiple sclerosis. Curr Opin Investig Drugs. 2010;11(11):1313-1323.

71. Merck Serono. Merck Serono: regulatory update on Cladribine tablets [press release]. Geneva: Merck; 2011 [June 22]. Available from: http:// www.merckserono.com/corp.merckserono_2011/en/images/20110622_ en_tcm1494_76074.pdf. Accessed February 24, 2012.

72. Portaccio E. Evidence-based assessment of potential use of fingolimod in treatment of relapsing multiple sclerosis. Core Evid. 2011;6:13-21.

73. Cohen JA, Barkhof F, Comi G, et al; for TRANSORMS Study Group. Oral fingolimod or intramuscular interferon for relapsing multiple sclerosis. $N$ Engl J Med. 2010;362(5):402-415.

74. Kappos L, Radue EW, O'Connor P, et al; for FREEDOMS Study Group. A placebo-controlled trial of oral fingolimod in relapsing multiple sclerosis. N Engl J Med. 2010;362(5):387-401.
75. Polman C, Barkhof F, Sandberg-Wollheim M, Linde A, Nordle O, Nederman T. Treatment with laquinimod reduces development of active MRI lesions in relapsing MS. Neurology. 2005;64(6): 987-991.

76. Comi G, Pulizzi A, Rovaris M, et al; for LAQ/506 Study Group. Effect of laquinimod on MRI-monitored disease activity in patients with relapsing-remitting multiple sclerosis: a multicentre, randomised, double-blind, placebo-controlled phase IIb study. Lancet. 2008;371(9630):2085-2092.

77. American Academy of Neurology (AAN) 63rd Annual Meeting: Abstract P05.288. Presented April 12, 2011.

78. Teva Pharmaceuticals Inc. Investigational laquinimod demonstrates its potential as a new oral treatment for RRMS [press release]. Jerusalem and Lund, Sweden: Teva; 2011 [October 19]. Available from: http:// www.tevapharm.com/en-US/Media/News/Pages/2011/1618694.aspx. Accessed February 24, 2012.

79. Kappos L, Gold R, Miller DH, et al; for BG-12 Phase IIb Study Investigators. Efficacy and safety of oral fumarate in patients with relapsing-remitting multiple sclerosis: a multicentre, randomised, double-blind, placebo-controlled phase IIb study. Lancet. 2008;372(9648):1463-1472.

80. Biogen Idec. Biogen Idec announces positive top-line results from the first Phase 3 trial investigating oral BG-12 (DIMETHYL FUMARATE) in multiple sclerosis [press release]. Weston, MA: Biogen Idec; 2011 [April 11]. Available from: http://www.biogenidec.com/press_release_ details.aspx?ID=5981\&ReqId=1548648. Accessed February 24, 2012.
Degenerative Neurological and Neuromuscular Disease

\section{Publish your work in this journal}

Degenerative Neurological and Neuromuscular Disease is an international, peer-reviewed, open access journal focusing on research into degenerative neurological and neuromuscular disease, identification of therapeutic targets and the optimal use of preventative and integrated treatment interventions to achieve improved outcomes, enhanced

\section{Dovepress}

survival and quality of life for the patient. The manuscript management system is completely online and includes a very quick and fair peer-review system. Visit http://www.dovepress.com/testimonials.php to read real quotes from published authors. 